\title{
Regenerative therapy by endometrial mesenchymal stem cells in thin endometrium with repeated implantation failure. A novel strategy
}

\author{
Alberto E Tersoglio ${ }^{1}$, Sebastian Tersoglio ${ }^{1}$, Dante R. Salatino ${ }^{1}$, Matías Castro ${ }^{1}$, Adriana Gonzalez ${ }^{1}$, Mariana \\ Hinojosa ${ }^{1}$, Onias Castellano ${ }^{1}$
}

${ }^{1}$ International Center for Assisted Reproduction, Mendoza, Argentina

\begin{abstract}
Objective: Our primary objective was to evaluate the endometrial changes before and after the transfer of endometrial mesenchymal stem cells (enMSCs) in a population of thinned endometrium women, with absence or hypo-responsiveness to estrogen and repeated implantation failure (RIF). The secondary objective was to evaluate the clinical outcomes of the intervention in terms of clinical pregnancy $(\mathrm{CP})$, early abortions, ongoing pregnancy and live birth delivery rate (LBDR) per in vitro fertilization (IVF) cycle.

Methods: A longitudinal and experimental study. The intervention was defined as "subendometrial inoculation of enMSCs," and the post-intervention changes were evaluated by the following variables: endometrial thickness (Eth), endometrial flow cytometry (enFC), endometrial histopathology (enHP) and endometrial immunohistochemistry (enIHQ). The variables were analyzed after the intervention (Post-treatment) regarding previous values (Pretreatment).

Results: Eth values before and after treatment with enMSCs were $5.24 \pm 1.24 \mathrm{~mm}$ vs. 9.93 $\pm 0.77(p=0.000)$, respectively. Endometrial Flow Cytometry showed significant differences in favor of Normalized variables in the post-treatment assessment, associated with the pretreatment, $\mathrm{LT} / \mathrm{Li}, \mathrm{LB} / \mathrm{Li}, \mathrm{NK} / \mathrm{Li}, \mathrm{CD} 8 / \mathrm{CD}^{+}$and $\mathrm{CD} 4 / \mathrm{CD} 8$ $(p \leq 0.015)$, respectively. Only two variables Li/PC and CD4/ CD3 had NS $(p=0.167$ and 0.118$)$. A similar analysis was performed on enHP with an HP increase post-treatment $(p=0.007)$. The CP rate was $79.31 \%(23 / 29)$, a live birth delivery rate per embryo transfer was $45.45 \%(10 / 22)$ and ongoing pregnancy $7 / 29$ (24.14\%).
\end{abstract}

Conclusion: Subendometrial enMSCs inoculation produces a significant increase in endometrial thickness; normalize the enHP, enIHQ and enFC. As a result, IVF after treatment with enMSCs yields a higher rate of $\mathrm{CP}$ and LBDR.

Keywords: endometrial mesenchymal stem cells, thin endometrium, repeated implantation failure, chronic endometritis, endometrial flow cytometry, endometrial histopathology

\section{INTRODUCTION}

One in nine couples in Europe and the USA is affected by implantation disorders, and it is estimated that RIF has a prevalence of $15-20 \%$ in IVF (Teklenburg et al., 2010; Cicinelli et al., 2008). There is enough evidence that appropriate Eth is essential for a successful pregnancy (Kovacs et al., 2003), and a thin endometrium is associated with low pregnancy rates (El-Toukhy et al., 2008; Glissant et al., 1985; Dickey et al., 1992). The optimal endometrial thickness (Eth) for conception remains controversial among clinicians. Eth less than $7 \mathrm{~mm}$ on ultrasound is generally considered sub-optimal for embryo transfer (Eftekhar et al., 2018). Approximately $0.6-0.8 \%$ of patients do not reach minimum thickness for embryo transfer (Al-Ghamdi et al., 2008). It has been stated that the probable causes of thin endometrium are as follows: inflammatory causes (acute or chronic endometritis/CE); iatrogenic (repeated curettage, polypectomy; hysteroscopic (myomectomy or laparoscopic) where the cavity is opened, and the irrational use of clomiphene citrate (Mahajan \& Sharma, 2016). It is also indicated that thin endometrium may be a result of an individual uterine structural pattern (Scioscia et al., 2009).

In spite of the large variety of treatment, most of the choices achieve only minor modifications in endometrium thickness and have not been validated (Eftekhar et al., 2018). Angiogenesis is the formation of new blood vessels from existing vascular structures by elongation, intussusception or sprouting of endothelial cells; and after birth, vascularization is determined and maintained by angiogenesis (Ahmed ( El-Badri, 2017). Physiological angiogenesis does not occur in most organs in the adult. However, endometrium is the site where normal angiogenesis take place, and it is a fundamental process in the menstrual cycle as well as in embryo implantation (Gordon et al., 1995). Rogers et al. (1998) suggested that endometrial angiogenesis occurs by elongation and intussusception rather than sprout formation. Blood vessels consist of an inner endothelial cell layer lining the vessel wall and perivascular pericytes, also known as mural cells, which envelop the vascular tube surface.

Pericytes are multipotent cells that are heterogeneous in their origin, function, morphology and surface markers (Ahmed ( El-Badri, 2017). Analysis of the anatomic relationship between pericytes and endothelial cells shows that they interact closely via juxtacrine or paracrine signaling (Gaengel et al., 2009). Pericytes were reported to respond to platelet derived growth factor receptor-B(PDGF-B) and transforming growth factorB(TGF-B) which are released by platelets after an injury (Mills et al., 2013). This chemotactic response to PDGF-Bleads to the migration of pericytes to the outer layer of the blood vessel. This migration enables the endothelial cells to proliferate at the wound site in response to vascular endothelial growth factor-VEGF (Möhle et al., 1997). Angiogenesis plays a key role in endometrium remodeling, being the vascular endothelial growth factor (VEGF) an important regulator of this process. A number of studies have reported that VEGF is expressed differentially in thin endometrial (Sugino et al., 2002; Kashida et al., 2001; Sharkey et al., 2000; Miwa et al., 2009). 
Uterine NK cells (UNK) are a major source of cytokines and angiogenic growth factors (Lash et al., 2006) including VEGF-A, placental growth factor (PLGF), and angiopoietin (Trundley \& Moffett, 2004), which may produce cytokines to promote angiogenesis during embryo implantation. Although uNK cell counts are increased in women with recurrent miscarriages (RM) and RIF, angiogenesis seems to be paradoxical in the two groups of women, namely increased in RM and reduced in RIF (Chen et al., 2017a). Previous studies have shown that isolated CD56+ uNK cells from women with RIF produce lowest levels of angiogenic factors, such as VEGF, PLGF, PDGF-BB, compared with women with RM and fertile controls (Chen et al., 2016). It has been proposed that angiogenesis may be reduced by stimulating the STAT5 pathway in uNK cells in women with RIF (Chen et al., 2017b). There is sufficient evidence of the existence of SCs in the human endometrium and the likelihood that they are a therapeutic resource in endometrial atrophy, thinned endometrium and Asherman syndrome (Singh et al., 2014). The skill to maintain a normal karyotype after several passages (Allickson et al., 2011), the ability to differentiate into multiple cell lines under standard culture (Rossignoli et al., 2013; Gargett et al., 2016), its immunosuppressive properties (inhibits LT, LB and NK) (Ribeiro et al., 2013), make endometrial mesenchymal cells (enMSCs) a source of excellence in certain regenerative therapies. These immunomodulatory properties are explained by the release of inflammatory cytokines in the tissue (Bernardo \& Fibbe, 2013).

On the other hand, the low immunogenic capacity and tumor genicity makes it the choice in clinical application (Zhou et al., 2011). An important concept is that both infection and inflammation may inhibit regeneration of traumatized endometrium through damage to the stem/progenitor cells by effector molecules, which also contribute to the deposition of fibrotic tissue (Gargett \& Ye, 2012). Oocyte donation cycles are ideal to measure the independent effect of Eth as a parameter of endometrial receptivity, because there is lower variability in embryo quality. RIF is a clinical entity which refers to a situation when implantation has repeatedly failed to reach a stage recognizable by pelvic sonography. It represents a very frustrating condition for both the healthcare professional and the patient.

In order to isolate the endometrium as the main responsible for RIF, different embryonic condition and a number of consecutive failed IVF cycles have been proposed. There is a tacit acceptance of defining RIF as the impossibility of obtaining clinical pregnancy after three consecutive IVF attempts, in which one to two embryos of high-grade quality are transferred in each cycle (Simon \& Laufer, 2012). The precise definition remains controversial, so other suggestions have been proposed (Polanski et al., 2014). Today, the most accepted definition of RIF, is a failure to achieve a clinical pregnancy after the transfer of three or more good-quality embryos in women $<35$ years of age, and four or more good quality embryos in women (35years during fresh or frozen embryo transfer cycles (Coughlan et al., 2014). In the presence of RIF of endometrial origin, the chronic endometritis (CE) and limited immunological alterations are plausible for specific treatments (Coughlan et al., 2014). In women with chronic endometritis (CE), the endometrial immune responses are often shifted towards pro-inflammatory profiles and are consequently unfavorable to invading embryos (Park et al., 2016). The high association between Chronic Endometritis (CE) and RIF is established (14\%-31\%), of unknown etiology (28\%) and recurrent pregnancy loss (9-13\%) (Johnston-MacAnanny et al., 2010; Cicinelli et al., 2005; Tersoglio et al., 2015; Bouet et al., 2016; Kotaro et al., 2017). A recent publication shows that $34.4 \%$ of women with RIF have CE, which is higher than those of women with recurrent pregnancy loss or fetal death (Wang et al., 2019).

The impact of chronic endometritis on perinatal outcomes has been considered, taking CP and LBR with/without treatment (56vs.7\%) into account (McQueen et al., 2014). It has been proven that CE yielded significantly decreased TGF-B and IL-10 expression in the endometrium, which reflects T-regulatory (Treg) cells in number or functional deficiency (Wang et al., 2019). EC resolution is of such complexity that the bacteriological clearance is inefficient as a criterion of cure, which could explain the high rate of persistent CE found (24.6 and $17.6 \%$ ) (Cicinelli et al., 2015; Cicinelli et al., 2018).

Our primary objective was to evaluate the endometrial changes before and after enMSCs transfer in a thinned endometrium population, with absence or hypo-responsiveness to estrogen. The secondary objective was to evaluate the results of the intervention in terms of $\mathrm{CP}$, early abortions, ongoing pregnancy and live births in IVF cycles.

\section{MATERIAL AND METHODS}

It is a longitudinal and experimental study focused on the endometrium (Salatino, 2019). The intervention was defined as "subendometrial inoculation of enMSCs" and the post-intervention changes were evaluated by the following variables: Eth $(\mathrm{mm})$, enFC and enHP. The variables were analyzed after the intervention (Post-treatment) in reference to the previous values (Pretreatment). A Binomial distribution was obtained through the dichotomization of the enHP and enCF (Normal or Abnormal) variables, the latter in relation to the $95 \%$ CI values of reference.

\section{Definition of thinned endometrium and RIF}

Thinned endometrium was considered to be the one that after twenty days of estrogen supplementation with an $8 \mathrm{mg} /$ day dose of 17Bestradiol did not reach at least 7 $\mathrm{mm}$ of Eth, measured in the midsagittal plane by transvaginal ultrasound (TVU). In ovulatory patients the endometrial thickness was checked on the day of LH and confirmed under the regimen described beforehand. We consider RIF as the absence of implantation after three or more cycles of IVF/ICSI or cryotransfer, where the cumulative number of embryos transferred was no less than three blastocysts with high quality $311-411$ or 511 of Gardner-Schoolcraft, the latter under the Istanbul criteria (Alpha Scientists in Reproductive and ESHRE special interest group of Embryology, 2011).

\section{Patient selection}

We selected 29 patients with thin endometrium, hyporesponsive/unresponsive to estrogens, with RIF. The inclusion criteria were absence of uterine malformation; autoimmune thyroid disease; thrombophilia; polyps; hydrosalpinx; and those who did not accomplish enHP, enIHQ and enFC pre/post-treatment; with the presence of normal uterine cavity ascertained by hysterosonography or hysteroscopy. In 23/29 (79.31\%)there were oocyte donations and6/29 (20.69\%) autologous cycles. The age of patients (in years), number of previous IVF cycles, body mass index and length of sterility (year) were calculated with Mean \pm DS and (interval); 41.72 \pm 5.18 (32$53), 4.03 \pm 1.65$ (3-8), 24.84 $5.09(19-40), 13.66 \pm 5.81$ (5-20), respectively. The measure of basal Eth $(\mathrm{mm})$ was $5.24 \pm 1.24(2-6.9)$. In $6 / 29(20.69 \%)$ they presented a history of uterine interventions (myomectomy $=3$, septum resection $=1$ and repetitive curettage=2). 6/29(20.69\%) patients showed CE after being with specific antibiotics, in whom IMH was normalized. The basal pretreatment histopathology was normal in $6 / 29(20.69 \%)$, and $23 / 29$ $(79.31 \%)$ presented abnormal patterns (Table 1 ). 


\begin{tabular}{|l|c|}
\hline $\begin{array}{l}\text { Table 1. Demographic, patient and basal clinical } \\
\text { characteristics }\end{array}$ \\
\hline Number of cycles/patient & 29 \\
\hline Number of previous IVF cycles & $4.03 \pm 1.65(3-8)$ \\
\hline Body Mass Index $\left(\mathrm{Kg} / \mathrm{m}^{2}\right)$ & $24.84 \pm 5.09(19-40)$ \\
\hline Patient age (year) & $41.72 \pm 5.18(32-53)$ \\
\hline Length of sterility (year) & $13.66 \pm 5.81(5-20)$ \\
\hline $\begin{array}{l}\text { Basal endometrial thickness } \\
\text { (mm) }\end{array}$ & $5.24 \pm 1.24(2-6.90)$ \\
\hline $\begin{array}{l}\text { No Patient w/ Previous Uterine } \\
\text { Interventions }\end{array}$ & $6 / 29(20.69 \%)$ \\
\hline $\begin{array}{l}\text { No Patient w/ Previous CE by } \\
\text { IHQ }\end{array}$ & $8 / 29(27.59 \%)$ \\
\hline Oocyte donation cycles & $23 / 29(79.31 \%)$ \\
\hline Homologous cycles & $6 / 29(20.69 \%)$ \\
\hline Endometrial biopsy & $6 / 29(20.69 \%)$ \\
\hline \multicolumn{1}{|c|}{ Normal } & $23 / 29(79.31 \%)$ \\
\hline \multicolumn{1}{|l|}{ Abnormal } & \\
\hline
\end{tabular}

Note: Values were represented by mean \pm DS. (Interval or $\%$ ) where correspond

\section{Endometrium Thickness and Endometrial Biopsy}

The endometrial thickness was measured in the middle sagittal section by transvaginal sonography (TVS), using a volumetric vaginal probe. The endometrial thickness in pre/pos-treatment was the highest value achieved under estrogen therapy upon progesterone administration onset. We obtained at least two endometrial biopsies from each patient, the first prior to treatment and the second after treatment with enMSCs. All biopsies were carried out under hormone replacement therapy (HRT), starting with 17( estradiol $8 \mathrm{mg} /$ day per os, for at least 20 days. The progesterone gel is added in an intravaginal dose of $180 \mathrm{mg} /$ day. The biopsies were made using the Cornier's pipelle, with axial movements on the entire endometrial surface in order to ensure an ideal harvesting.

Histopathological and bacteriological criteria for normal and abnormal endometrium

The histopathological criteria for dating were those corresponding to Noyes et al. (1950). In case of a CE history, the pretreatment biopsy must accomplish the bacteriological clearance with an endometrial stromal plasmocyte density index (ESPDI $(0.25)$ as a cure criterion (Akopians et al., 2015; Kitaya et al., 2017). ESPDI was the result from the sum of the stromal CD138 cell counts divided by the number of HPFs evaluated. The following histopathological criteria were considered for an abnormal endometrium: 1) lymphocyte clusters, 2) polymorphic inflammatory cells (stromal, superficial epithelium and intraglandular), 3) superficial mucosal edematous change, 4) presence of fibroblast-like stromal cells (spindle stroma) (Check et al., 1991), 5) high-density stromal cells, 6) pseudo-stratification and mitotic nuclei in both glandular and surface epithelial cells, 7) micro polyps, 8) delayed endometrium differentiation (out of phase). Having no more than three of the previously established criteria was required as a post-treatment standardization, as per depicted in Figure 1.

The bacteriological test consisted of a freshtest with Gram/Giemsa staining and culture in Thayer Martin medium, sheep blood agar, and chocolate agar, Agar medium Saboreaud, and EMB/CLDE of vaginal and endocervical samples, and endometrium washing with PBS. Chlamydia trachomatis was tested using immunofluorescence; Mycoplasma hominies and Urea plasma urealyticum using Mycofast-urea/arginine. All the cases included in the present study required negative bacteriology before the enMSCs treatment.

\section{Endometrial Multicolour Flow Cytometry}

A four colors and six parameters FACS Calibur two lasers, (Bexton Dickinson(r)) was used for cytometric evaluation. The following variables were considered: Li/PC (total lymphocyte/total cell population ratio), T-lymphocytes (LT), B lymphocytes (LB) and NK (NK) cells over Li; CD3+ CD4+, CD3+ CD8+, CD4/CD8 ratio and NK CD56/CD16 subpopulations. We established a normal reference group for the cytometric variables $(n=25)$, corresponding to oocyte donors with a normal reproductive history (absence of abortions, with normal live births, no history of vaginosis, negative endometrial bacteriology and normal endometrial pathological anatomy) (Table 2). The values obtained in this study were considered for each variable as normal or abnormal, as per related to the reference group.

\section{Cell isolation and culture}

The endometrial tissue was dissociated using enzymatic and mechanical dissociation, and separated into stromal single-cell suspensions and epithelial clumps as previously described with several modifications (Allickson et al., 2011; Akopians et al., 2015; Chen et al., 2016). Endometrial tissue samples were washed in DMEM/F-12 w/15mM HEPES buffer (Gibco,\#11330-032), 5\% newborn calf serum (Invitrogen), and $1 \%$ antibiotic-antimycotic, (Gibco,\#15240-062) (Bench Medium), then weighed and cut into small pieces $<1 \mathrm{~mm}^{3}$. The tissue fragments were digested with $0.5 \%$ (wt/vol) type IV collagenase (Gibco,\#17104-019) and $40 \mu \mathrm{g} / \mathrm{ml}$ type I deoxyribonuclease (Worthington Biochemical Corporation) in DMEM/F-12 for $1.5 \mathrm{~h}$ at $37^{\circ} \mathrm{C}$ in a stirring machine. Typically, $10 \mathrm{ml}$ of the cell dissociation medium was used per $1 \mathrm{~g}$ tissue. The dissociated cells were filtered through a sterile $40-\mu \mathrm{m}$ cell strainer (BD Biosciences, Durham, NC, USA).

Most of the stromal cells and blood cells were present as a single-cell suspension, passed through the cell strainer into a sterile $50-\mathrm{ml}$ polycarbonate tube, whereas the undigested fragments, mostly comprised of glandular clumps, were retained in the strainer. Stromal single-cell suspensions were layered over Ficoll-Paque PLUS (GE Healthcare Bio-Sciences AB, \#17-1440-02) and centrifuged to remove the red blood cells. The medium/Ficoll interface, mainly containing stromal cells and peripheral blood mononuclear cells, was carefully aspirated, washed with Bench Medium, and then subjected to culture. Endometrial stromal cells were seeded at a clonal density of $50-100$ cells $/ \mathrm{cm}^{2}$ in two flasks of $75 \mathrm{~cm}^{2}$ and $25 \mathrm{~cm}^{2}$ (Biofil\#TCF011250,TCF011050) with DMEM/F-12 plus wo/Hepes (GIBCO, 11320-033) supplemented with $10 \%$ newborn calf serum (Invitrogen), $5 \%$ Anti-Anti (Gibco) and $2 \mathrm{mM}$ Glutamine (Invitrogen) up to obtain total confluence. When the cells reached $75 \%$ confluence, they were detached using a 0,125\% trypsin solution (GIBCO,\#27250-018), diluted and plated onto new $T$ flasks. The cells were sub-cultured by the third passage and cryopreserved (Amable et al., 2013a).

\section{enMSC culture immunophenotyping}

In the confluent stage, the cells were characterized by the flow cytometry, previously marked using the Human MSC analysis Kit (BD biosciences\#562245) (CD19, CD34, CD45, CD73, CD90, CD105, HLA-DR). Under the recommendations of the International Society for Cellular Therapy, MSCs should be positive for CD73, CD90 and CD105, but negative for CD34, CD45, CD11b or CD14, CD19 or 

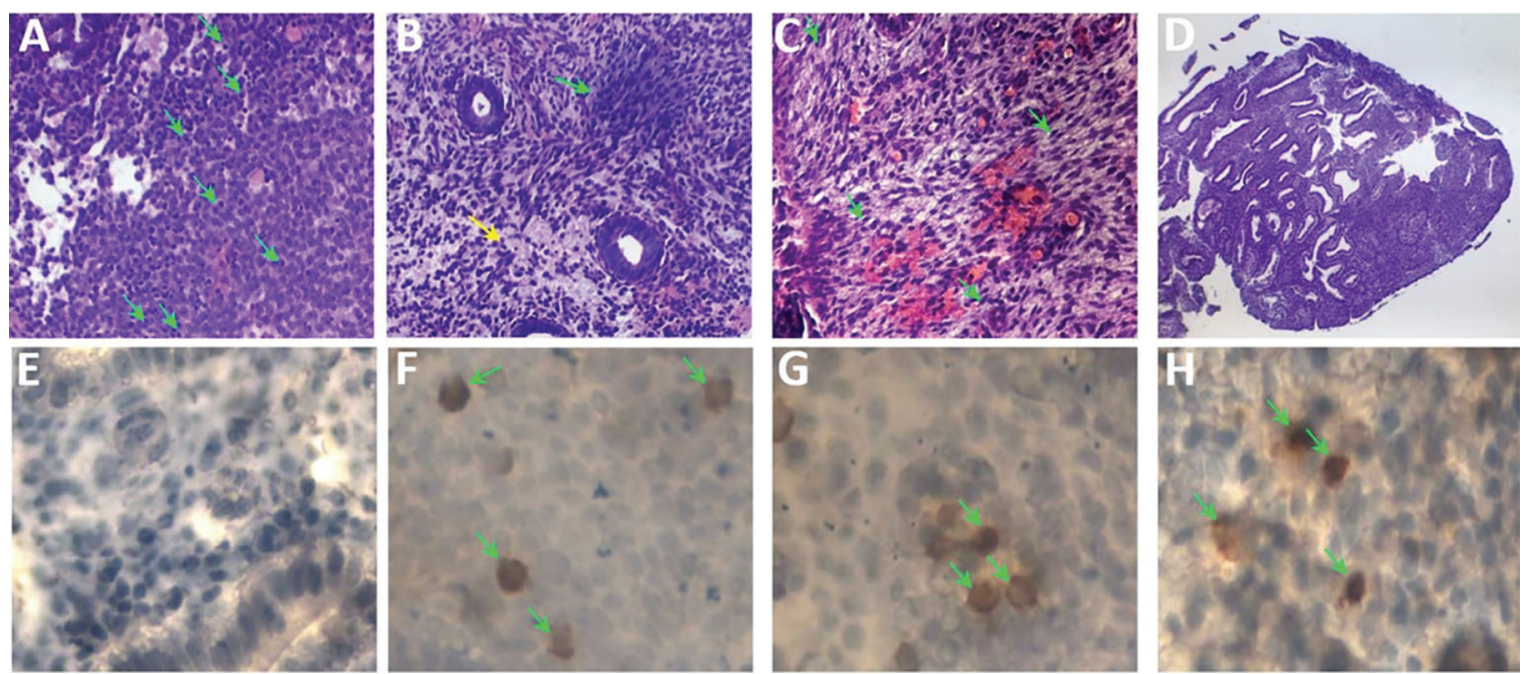

Figure 1. Staining of tissue samples showing (A) Plasmatic Cells, (B) Stromal edema and elevated Stromal density, (C) Spindle Stromal cells, (D) micropolyps, (E) Normal CD138, (F) High CD138, (G) High CD56 and $(\mathbf{H})$ High CD20

\begin{tabular}{|l|c|c|c|}
\hline Table 2. Endometrial Flow Cytometry. Normal Reference Value \\
\hline Variables $-\boldsymbol{n}=\mathbf{2 5}$ & Mean $\mathbf{2 S D}$ & $\mathbf{9 5 \%}$ CI & pvalue \\
\hline $\mathrm{LT} / \mathrm{Li}$ & $51.96 \pm 16.05$ & $35.908-68.01$ & $0.112^{*}$ \\
\hline $\mathrm{NK} / \mathrm{Li}$ & $40.04 \pm 14.58$ & $25.458-54.62$ & $0.157^{*}$ \\
\hline CD4/Li & $44.32 \pm 7.78$ & $36.539-52.1$ & $0.324^{*}$ \\
\hline CD8/Li & $56 \pm 12.31$ & $43.6912-68.31$ & $0.729^{*}$ \\
\hline CD4/CD8 & $0.64 \pm 0.38$ & $0.2676-1.01$ & $0.137^{*}$ \\
\hline Li/Cells population & $5.6^{*}$ & $2-6.27$ & $0.000^{+}$ \\
\hline LB/Li & $2^{*}$ & $1-2.98$ & $0.000^{+}$ \\
\hline
\end{tabular}

* $p>0.05$ Normal distribution; ${ }^{+} p<0.05$ No Normal distribution (by Shapiro Wilk test);

$\mathrm{CI}=$ Confidence interval; $\mathrm{SD}=$ Standard deviation; ${ }^{*}$ Median

CD79(, and HLA-DR. Additionally, SUSD2/W5C5 and CD140b (PDFGF-RB ${ }^{+}$) (BD biosciences, \# 558821, 566657, respectively)were used as a positive marker. When the cell population reached the degree of confluence, usually in passage 5 to 7 and the cytometry results show less than $0.3 \%$ for CD19, CD34, CD45 and HLA-DR, and more than $99.9 \%$ for the markers, CD73, CD90 and CD105 were transferred under sonographic control using a transvaginal probe. In all cases, enMSCs transfer was carried out in the estrogenic phase under estrogen supplementation for 6 to 8 weeks.

\section{enMSCs cryopreservation}

The residual flasks were cryopreserved in a suspension solution with $50 \%$ DMEM/F12, supplemented with $40 \%$ Fetal Bovine Serum (Internegocios, Argentina) and 10\% DMSO (MP Bio, USA). The cells suspended in the medium were frozen at $-4^{\circ} \mathrm{C}$ for one hour and then at $-70^{\circ} \mathrm{C}$ for 24 hours and finally transferred to the N2 tank in cryotubes. In the warm-up phase, the tubes are transferred to a water bath at $37^{\circ} \mathrm{C}$ and resuspended with the DMEM/F12 solution with $10 \%$ FBS and centrifuged at 1,200 rpm for 7 minutes. Viability was evaluated with $0.4 \%$ Tryptan Blue (SIGMA\#T8154) in PBS.

\section{Platelet-Rich Plasma Preparation}

The plasma platelets concentrate obtained by centrifugation of the patient's whole blood was named PRP and this was applied as a diluent for the enMSCs. The peripheral blood was collected using tubes containing 3.2\% sodium citrate solution. The preparation protocol was divided into two centrifugation steps. In the first centrifugation, the relative centrifugal force applied was $300 \times \mathrm{g}$ for $5 \mathrm{~min}$ at $18^{\circ} \mathrm{C}$. The whole plasma above the buffy coat was collected (PRP1) and transferred to a new tube. The second centrifugation step used $700 \times \mathrm{g}$ for $17 \mathrm{~min}$ at $18^{\circ} \mathrm{C}$. The platelet-poor plasma (PPP) was transferred to a new tube. The platelet pellet obtained from $1 \mathrm{ml}$

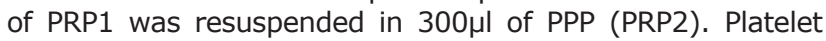
activation was induced by adding $20 \mathrm{mM} \mathrm{CaCl} 2$ and $25 \mathrm{IU} / \mathrm{ml}$ human thrombin incubated at $37^{\circ} \mathrm{C}$ for $1 \mathrm{~h}$ or at $4^{\circ} \mathrm{C}$ for $16 \mathrm{~h}$. Finally, for recovering the activated PRP2, the samples were centrifuged at $3000 \times \mathrm{g}$ for $20 \mathrm{~min}$ at $18^{\circ} \mathrm{C}$ and the supernatant (activated PRP2) was collected by aspirating Activated $\mathrm{PRP}$, hereafter referred to as PRP, and frozen at $-20^{\circ} \mathrm{C}$ until use (Amable et al., 2013a; 2013b).

\section{Transmiometrial transference of enMSC}

Before transferring, the enMSCs is harvested using a $0.125 \%$ trypsin solution (GIBCO, \#15090-046), washed 
with PBS and re-suspended in PBS containing 2\% FBS. Viable and total cell numbers were determined using Trypan blue in Neubauer chambers. The enMSCs were transferred in a number of 2.5 to $3.6 .10^{6}$ cells, diluted in $1 \mathrm{ml}$ of autologous PRP with the use of an Embryo Transfer Transmyometrial catheter (COOK \# K-TTET-19-32.5) after sedating the patient.

\section{Embryo laboratory, transfer, receptor protocol}

Having ovarian activity, the hypothalamus is suppressed with the use of depot GnRHa, Triptorelin $3.76 \mathrm{mg}$ in a single dose, or Leuprolide acetate in doses of 200 to $300 \mathrm{mi}-$ crograms/day, in a long regimen; beginning the estrogen replacement in the presence of a plasmatic estradiol $<30$ $\mathrm{pg} / \mathrm{ml}$. Both the Estradiol valerate and the $17 \beta$-estradiol were administered in increasing doses, orally, according to the endometrial response and established protocol. Five or six days before the transfer, we added progesterone gel in daily doses of $90 \mathrm{mg}$ per vaginal administration. In cases of inadequate endometrial response, we associated transdermal patch replacement with variable doses (50-150 micrograms every 2.5 days). All transfers were individualized according to previous biopsies and level of IHQ hormonal receptors. Only expanded or hatched optimum quality blastocysts (score 4.1.1 or 5.1.1) were transferred in a number no higher than two. In cases where a second blastocyst was of suboptimal quality $(412,421,512$ or 521) the transfer was made. In cases of a single embryo, the transfer (SET) was considered only when it were of optimal quality. All of the embryos at day 5 were cryopreserved and transferred at the time of endometrium optimization (Frozen-thawed embryo-transfer).

\section{Statistical Analysis}

Statistical analyses were performed using the SPSS version 20 (IBM) and the STATA statistical software version 14 (StataCorp). The data distribution was checked using the Shapiro-Wilk test. For the normal reference group, the $95 \%$ CI was calculated with the mean(2DS for the normal distribution data; median and range for skewed data. The endometrial thickness was compared in the pre and post-treatment using the paired samples t-test; for the enFC and enHP the McNemar test was applied. The level of significance was set at $p<0.05$. For the enFC, each variable was dichotomized as normal or abnormal vis-à-vis the reference values. Histopathology was normal in the post-treatment when a ( 3 abnormal pattern was observed.

\section{RESULTS}

A total of 29 cycles/patients were analyzed with a mean age of $41.03 \pm 4.52$, with a history of infertility for $13.66 \pm 5.81$ years, and $3.79 \pm 0.73$ previously failed IVF cycles; all with thin endometria. As depicted on table 3 , the Eth value between pre and post-treatment with enMSCs resulted in $5.24 \pm 1.24 \mathrm{~mm}$ vs. $9.93 \pm 0.77$ $(p=0.000)$, respectively. As displayed in Figure 2 , the endometrial thickness evolution on a case-by-case basis is represented individually in relation to the intervention with enMSCs, ratifying an increase of more than $8 \mathrm{~mm}$ in all cases.

As you can see in Table 3, after the dichotomization of the enFC variables (Normal or Abnormal), the lymphoid populations studied by FC showed significant differences in favor of Normalized variables in post-treatment. As a result: $\mathrm{LT} / \mathrm{Li}, \mathrm{LB} / \mathrm{Li}, \mathrm{NK} / \mathrm{Li}, \mathrm{CD} 8 / \mathrm{CD}^{+}$and CD4/CD8 ratios were normalized, $p=0.013,0.002$, $0.049,0.000,0.000$, respectively. Both variables ( $\mathrm{Li} / \mathrm{PC}$ and $C D 4 / \mathrm{CD}^{+)}$show a post-intervention increase, but it turns out to be NS ( $p=0.167$ and 0.118$)$. Analyses of the enHP variables were carried out according to the criteria previously described. We found a normal increase in post-treatment $(p=0.007)$.

As it is shown in Table 4, over 29 females with embryo transfer, 23/29 (79\%) were clinical pregnancies, from which there were live births 10/22 (45.5\%) and $7 / 29(24.14 \%)$, respectively, continued with their pregnancies with gestational ages greater than 17 weeks. The implantation rate resulted in $68.12 \%$, with a mean value of $1.86 \pm 0.34$ embryos transferred per patient. With a prematurity rate of $1 / 10(10 \%)$ and single delivery $7 / 10(70 \%)$.

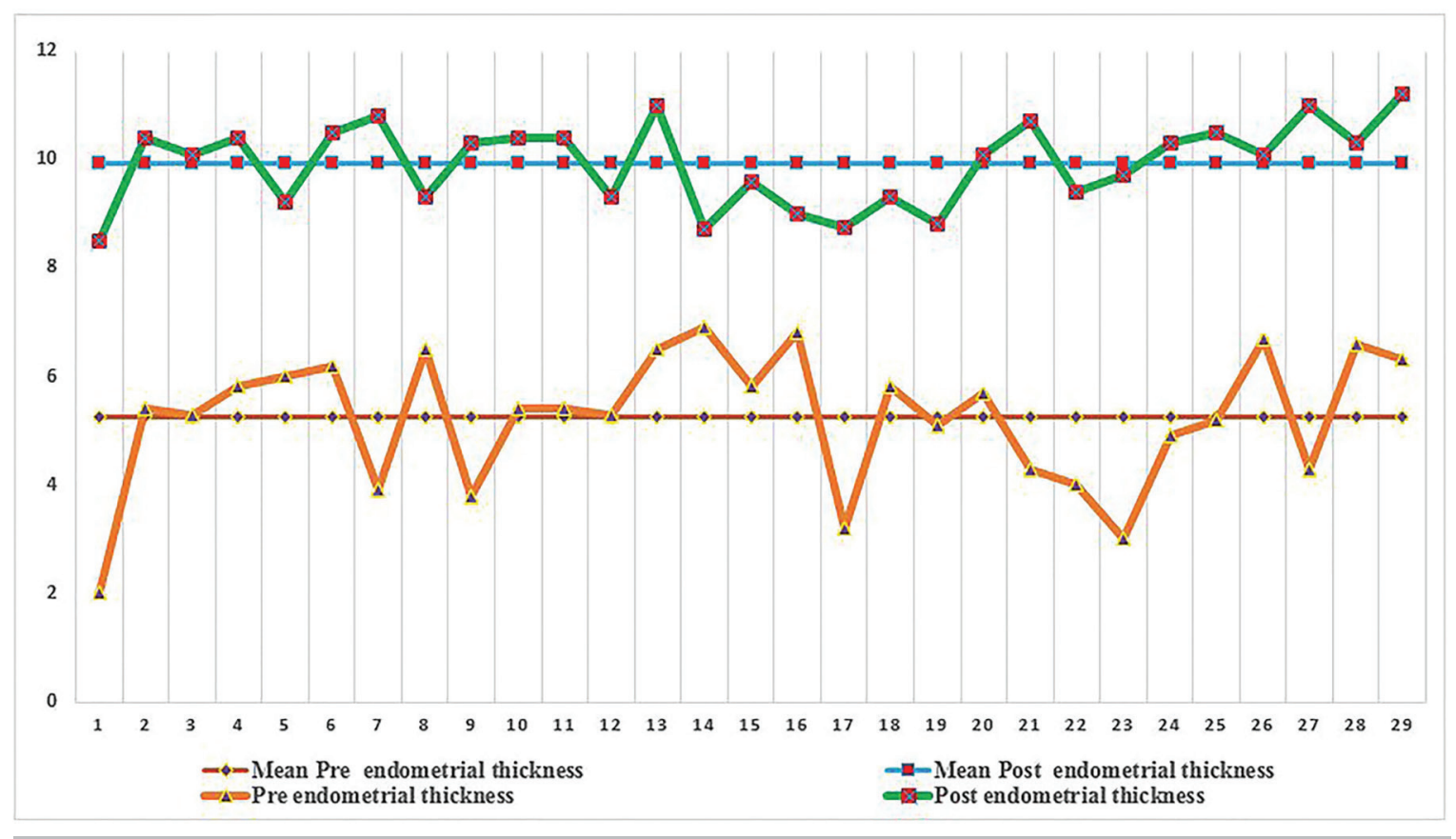

Figure 2. Individual evolution of endometrial thickness 


\begin{tabular}{|c|c|c|c|}
\hline Variables & Presc $_{\text {s }}$ & Post SC & $p$ value \\
\hline Endometrial Thickness & $5.25 \pm 1.24$ & $9.93 \pm 0.77$ & $0.000 *$ \\
\hline \multicolumn{4}{|c|}{ Endometrial Flow Cytometry } \\
\hline \multicolumn{4}{|l|}{$\mathrm{Li} / \mathrm{PC}$} \\
\hline Normal & $13 / 29(44.8 \%)$ & $20 / 29(69 \%)$ & \multirow{2}{*}{$0.167^{+}$} \\
\hline Abnormal & $16 / 29(55.2 \%)$ & $9 / 29(31 \%)$ & \\
\hline \multicolumn{4}{|l|}{ LT } \\
\hline Normal & $15 / 29(51.7 \%)$ & $26 / 29(89.7 \%)$ & \multirow{2}{*}{$0.013^{+}$} \\
\hline Abnormal & $14 / 29(48.3 \%)$ & $3 / 29(10.3 \%)$ & \\
\hline \multicolumn{4}{|l|}{ LB } \\
\hline Normal & $8 / 29(27.6 \%)$ & $18 / 29(62.1 \%)$ & \multirow{2}{*}{$0.002^{+}$} \\
\hline Abnormal & $21 / 29(72.4 \%)$ & $11 / 29(37.9 \%)$ & \\
\hline \multicolumn{4}{|l|}{ NK } \\
\hline Normal & $14 / 29(48.3 \%)$ & 23/29 (79.3\%) & \multirow{2}{*}{$0.049^{+}$} \\
\hline Abnormal & $15 / 29(51.7 \%)$ & $6 / 29(20.7 \%)$ & \\
\hline \multicolumn{4}{|l|}{ CD4 } \\
\hline Normal & $14 / 29(48.3 \%)$ & $21 / 29(72.4 \%)$ & \multirow{2}{*}{$0.118^{+}$} \\
\hline Abnormal & $15 / 29(51.7 \%)$ & $8 / 29(27.6 \%)$ & \\
\hline \multicolumn{4}{|l|}{ CD8 } \\
\hline Normal & $13 / 29(44.8 \%)$ & $25 / 29(86.2 \%)$ & \multirow{2}{*}{$0.000^{+}$} \\
\hline Abnormal & $16 / 29(55.2 \%)$ & $4 / 29(13.8 \%)$ & \\
\hline \multicolumn{4}{|l|}{ CD4/CD8 } \\
\hline Normal & $13 / 29(44.8 \%)$ & $28 / 29(96.6 \%)$ & \multirow{2}{*}{$0.000^{+}$} \\
\hline Abnormal & $16 / 29(55.2 \%)$ & $1 / 29(3.4 \%)$ & \\
\hline \multicolumn{4}{|c|}{ Endometrial Histopathology } \\
\hline Normal & $6 / 29(20.7 \%)$ & $17 / 29(58.6 \%)$ & \multirow{2}{*}{$0.007^{+}$} \\
\hline Abnormal & $23 / 29(79.3 \%)$ & $12 / 29(41.4 \%)$ & \\
\hline
\end{tabular}

* T-test paired samples, ${ }^{+}$McNemar Test.

\begin{tabular}{|l|c|}
\hline \multicolumn{2}{|l|}{ Table 4. Clinical and Pregnancy Outcome } \\
\hline $\mathrm{n}$ & 29 \\
\hline No of Embryo Transferred (mean \pm SD) & $1.86 \pm 0.34$ \\
\hline Implantation Rate (\%) & $68.12 \%$ \\
\hline Clinical Pregnancy (\%) & $\begin{array}{c}23 / 29 \\
(79.31 \%)\end{array}$ \\
\hline Abortion Rate (\%) & $6 / 29(20.69 \%)$ \\
\hline Ongoing Pregnancy (\%) & $7 / 29(24.14 \%)$ \\
\hline Live Birth Delivery Rate (\%)* & $10 / 22$ \\
\hline Single (\%) & $7 / 10(70 \%)$ \\
\hline Double (\%) & $3 / 10(30 \%)$ \\
\hline Premature Delivery & $1 / 10(10 \%)$ \\
\hline Birth weight< $2500 \mathrm{gr}$ & 5 \\
\hline Birth weight> $2500 \mathrm{gr}$ & 8 \\
\hline
\end{tabular}

* For Initiated Cycles

\section{DISCUSSION}

Thin endometrium may be conditioned by multiple factors, its management should be cause-related, with the aim of increasing endometrial receptivity and simplifying implantation (Lebovitz \& Orvieto, 2014). EnMSCs, for their properties of high clonality, multipotentiality, regenerative capacity, immunomodulatory, angiogenic and low immunogenicity are proposed as an alternative in severe endometrial lesions. Adequate uterine vascularity and the regulating cells/factors are needed at the time of implantation, while inappropriate endometrial angiogenesis and immunity may lead to reproductive failure, especially in recurrent miscarriage and RIF (Chen et al., 2017 a). A number of non-cellular treatments have been tried to increase endometrial development, but none has been validated so far. Endometrial stem cell research is gaining momentum and the knowledge generated may be translated into the clinical setting within the next decade (Gargett \& Ye, 2012). One of the points to be clarified is to define the cell line (s) that will be applied to the study, taking into account the limitations inherent to the method. The enSCs are a heterologous population that includes: mesenchymal stem 
cells (MSCs), epithelial stem cells (ESCs), endometrial side population (ESP) and endometrial regenerative cell (ERC) (Azizi et al., 2018).

The Endometrial Side Population (ESP) are a mixed population, comprising predominantly of precursors of endothelial cells (Masuda et al., 2010), and epithelial and stromal cells (Cervelló et al., 2010). The proportion of SP cells in whole and fractions of epithelial and stromal cells fluctuate from $0.06-6.2 \%$ and $0.01-3.8 \%$, respectively. The SP cells have the capability to extrude the DNA binding dye Hoechst 33342 via the ATP-binding cassette (Cervelló et al., 2010). They also exhibit high clonogenicity (Tsuji et al., 2008), telomerase activity (Cervelló et al., 2010), but the most important and controversial issue is the heterogeneity of SP cells (Masuda et al., 2015). Specific markers of human endometrial MSC have been identified. Coexpression of $\mathrm{CD} 140 \mathrm{~b}\left(\mathrm{PDFGF}-\mathrm{RB}^{+}\right.$) platelet-derived growth factor-receptor beta (Schwab \& Gargett, 2007), and W5C5 have been used to isolate endometrial mesenchymal stem cells (Masuda et al., 2012). The gene profile of this CD $146^{+}$ PDFGF-RB ${ }^{+}$population indicated that these cells expressed pericyte markers, and genes associated with angiogenesis/vasculogenesis, steroid hormone/hypoxia responses, inflammation, immunomodulation, and signaling pathways associated with MSCself-renewal and multipotency (Gargett \& Ye, 2012).

Epithelial progenitor cells (ESCs) is a small population with high proliferative potential, that differentiated into large gland-like structures (Nguyen et al., 2017). N-cadherin as a marker of epithelial progenitor cells can play a role in endometrial proliferative disorders like adenomyosis, endometriosis, and thin dysfunctional endometrium (Mills et al., 2013). The main limitation of EPCs recovery is their location, because they are placed near the basal gland fundus and close to the myometrium. Because of that, it is seldom observed in cell culture. Endometrial Regenerative Cells (ERC) have some features similar to MSC including the capability to modulate the immune system and stimulate Treg production. In this series, phenotyping indicates a predominance of MSCs, but probably due to sharing markers, the population has ESCs and ESP components. Actually, clinical application may not necessarily need a pure population of Stem Cells. However, for stem cell biology and understanding endometrial physiology, it is necessary to obtain single line cells (Masuda et al., 2015). A normal reference group was established for the cytometric variables $(n=25)$ in the absence of previously published data. All the variables were analyzed in the normality of their distribution and the $95 \%$ CI was calculated in order to increase data precision.

There was a highly significant increase in endometrial thickness after the inoculation of enMSCs, expressing the high regenerative capacity of the intervention. In 8/29 $(27.5 \%)$ cases, they presented pretreatment values with critical values of $<4 \mathrm{~mm}$, despite having been subjected to estrogen therapy for over 20 days. It is interesting to note that in most of the previous IVF treatments the endometrium had not been isolated as the main cause of the repeated failures, even though the majority of the medical therapies had been tried (high doses of estradiol, HCG, aspirin, sildenafil, vitamin E and granulocyte colony stimulating factor). Endometrial lymphoid population normalization should be a primary objective in any treatment where the implantation conditions have been modified. Endometrial NK cells are the major leucocytes source present in the endometrium. It has been established that $47 \%$ of RIF presented uNK cell counts outside the reference range, with a majority above the range and a smaller proportion below the range (Chen et al., 2017b). In the present study, baseline FC showed in all cases a profound alteration of the lymphoid population and a significant normalization after
enMSC. In this series a higher percentage of cytometric variables have been normalized, demonstrating the powerful modulator effect of enSCs. It is also interesting to see that in the subpopulation with CE background a high proportion shows alterations in the leukocyte population and the enMSCs were able to normalize 4/8 (50\%); the totality of normalized cases resulted in live births. In contrast with the rest of the $\mathrm{CE}$, none normalized after treatment with enMSCs, where $3 / 4$ cases failed pregnancy. The special behavior of uNK and its implication in angiogenesis have been indicated in previous studies, those who have shown that isolated CD56+uNK cells from women with RIF produce lower levels of angiogenic factors, such as vascular endothelial growth factor (VEGF), placental growth factor (PLGF), platelet-derived growth factor (PDGF-BB), compared with women with RM and fertile controls (Chen et al., 2016). Additional statistical treatment showed that the normalization of enNK increased significantly the $\mathrm{CP}$ and LBDR when compared with no normalization $(65.5 \%$ vs. $13.8 \%$ and $(44.8$ vs. $13.8 \%)$, respectively.

The CD4/CD8normalization ratio accomplished the highest CP and ongoing/LBDR (79.3\% and 58.6\%). A high abortion rate $(20.69 \%)$ was found, which indicates that there are other factors to be considered and cannot be explained by de variables analyzed. The strength of this study lies in the selection of the endometrium as an object of study and the measure of its effects in clinical results. The weakness of this study is that it failed to achieve a complete immunophenotyping of enMSCs and not angiogenic markers. Finally, the endometrium thickness and the standardization of histopathology and immunohistochemistry in post-treatment with enMSCs resulted in higher clinical pregnancy rates in a population with repeated implantation failures, representing a reliable strategy in Assisted Reproduction.

\section{CONFLICT OF INTERESTS}

No conflict of interest has been declared.

\section{Corresponding author:}

Alberto E. Tersoglio

International Center for Assisted Reproduction Mendoza, Argentina.

E-mail: tersoglioa@institutotersoglio.com.ar

\section{REFERENCES}

Ahmed TA, El-Badri N. Pericytes: The Role of Multipotent Stem Cells in Vascular Maintenance and Regenerative Medicine. In: Turksen K, ed. Cell Biology and Translational Medicine. Advances in Experimental Medicine and Biology. Volume 1079. Cham: Springer; 2017. p. 69-86.

Akopians AL, Pisarska MD, Wang ET. The Role of Inflammatory Pathways in Implantation Failure: Chronic Endometritis and Hydrosalpinges. Semin Reprod Med. 2015;33:298304. PMID: 26132934 DOI: 10.1055/s-0035-1554916

Al-Ghamdi A, Coskun S, Al-Hassan S, Al-Rejjal R, Awartani $\mathrm{K}$. The correlation between endometrial thickness and outcome of in vitro fertilization and embryo transfer (IVFET) outcome. Reprod Biol Endocrinol. 2008;6:37. PMID: 18764940 DOI: $10.1186 / 1477-7827-6-37$

Allickson JG, Sanchez A, Yefimenko N, Borlongan CV, Sanberg PR. Recent Studies Assessing the Proliferative Capability of a Novel Adult Stem Cell Identified in Menstrual Blood. Open Stem Cell J. 2011;3:4-10. PMID: 21686032 DOI: $10.2174 / 1876893801103010004$ 
Alpha Scientists in Reproductive Medicine and ESHRE Special Interest Group of Embryology. The Istanbul consensus workshop on embryo assessment: proceedings of an expert meeting. Hum Reprod. 2011;26:1270-83. PMID: 21502182 DOI: 10.1093/humrep/der037

Amable PR, Carias RB, Teixeira MV, Pacheco I, Amaral RJF, Granjeiro JM, Borojevic R. Platelet-rich plasma preparation for regenerative medicine: optimization and quantification of cytokines and growth factors. Stem Cell Res Ther. 2013a;4:67. PMID: 23759113 DOI: 10.1186/scrt218

Amable PR, Teixeira MVT, Carias RBV, Granjeiro JM, Borojevic R. Identification of Appropriate Reference Genes for Human Mesenchymal Cells during Expansion and Differentiation. PLoS One. 2013b;8:e73792. PMID: 24023904 DOI: $10.1371 /$ journal.pone.0073792

Azizi R, Aghebati-Maleki L, Nouri M, Marofi F, Negargar S, Yosefi M. Stem cell therapy in Asherman syndrome and thin endometrium: Stem Cell-based therapy. Biomed Pharmacother. 2018;102:333-43. PMID: 29571018 DOI: 10.1016/j.biopha.2018.03.091

Bernardo ME, Fibbe WE. Mesenchymal stromal cells: Sensors and switchers of inflammation. Cell Stem Cell. 2013;13:392-402. PMID: 24094322 DOI: 10.1016/j. stem.2013.09.006

Bouet PE, El Hachem H, Monceau E, Gariépy G, Kadoch IJ, Sylvestre C. Chronic endometritis in women with recurrent pregnancy loss and recurrent implantation failure: prevalence and role of office hysteroscopy and immunohistochemistry in diagnosis. Fertil Steril. 2016;105:106-10. PMID: 26456229 DOI: 10.1016/j.fertnstert.2015.09.025

Cervelló I, Gil-Sanchis C, Mas A, Delgado-Rosas F, Martínez-Conejero JA, Galán A, Martínez-Romero A, Martínez S, Navarro I, Ferro J, Horcajadas JA, Esteban FJ, O'Connor JE, Pellicer A, Simón C. Human endometrial side population cells exhibit genotypic, phenotypic and functional features of somatic stem cells. PLoS One. 2010;5:e10964. PMID: 20585575 DOI: 10.1371/journal. pone.0010964

Check JH, Nowroozi K, Choe J, Dietterich C. Influence of endometrial thickness and echo patterns on pregnancy rates during in vitro fertilization. Fertil Steril. 1991;56:1173-5. PMID: 1743341 DOI: 10.1016/S0015-0282(16)54736-0

Chen X, Liu Y, Jiang L, Wang CC, Li TC. Angiogenic cytokine profiles of human uterine CD56+ natural killer cells in women with recurrent reproductive failure. Am J Reprod Immunol. 2016;76 (Suppl. 1): 19-28. DOI: 10.1111/ aji. 12580

Chen X, Man GCW, Liu Y, Wu F, Huang J, Li TC, Wang CC. Physiological and pathological angiogenesis in endometrium at the time of embryo implantation. Am J Reprod Immunol. 2017a;78:e12693. PMID: 28466568 DOI: 10.1111/aji.12693

Chen X, Mariee N, Jiang L, MPhil YL, Wang CC, Li TC, Laird $\mathrm{S}$. Measurement of natural killer cell percentage in the periimplantation endometrium from fertile women and women with recurrent reproductive failure: establishment of a reference range. Am J Obstet Gynecol. 2017b;217:680. e1-6. PMID: 28935491 DOI: 10.1016/j.ajog.2017.09.010
Cicinelli E, Resta L, Nicoletti R, Zappimbulso V, Tartagni M, Saliani N. Endometrial micropolyps at fluid hysteroscopy suggest the existence of chronic endometritis. Hum Reprod. 2005;20:1386-9. PMID: 15734762 DOI: 10.1093/ humrep/deh779

Cicinelli E, De Ziegler D, Nicoletti R, Colagiglio G, Saliani N, Resta L, Rizzi D, De Vito D. Chronic endometritis: correlation among hysteroscopic, histologic, and bacteriologic findings in a prospective trial with 2190 consecutive office hysteroscopies. Fertil Steril. 2008;89:677-84. PMID: 17531993 DOI: $10.1016 /$ j.fertnstert.2007.03.074

Cicinelli E, Matteo M, Tinelli R, Lepera A, Alfonso R, Indraccolo U, Marrochella S, Greco P, Resta L. Prevalence of chronic endometritis in repeated unexplained implantation failure and the IVF success rate after antibiotic therapy. Hum Reprod. 2015;30:323-30. PMID: 25385744 DOI: $10.1093 /$ humrep/deu292

Cicinelli E, Matteo M, Trojano G, Mitola PC, Tinelli R, Vitagliano A, Crupano FM, Lepera A, Miragliotta G, Resta L. Chronic endometritis in patients with unexplained infertility: Prevalence and effects of antibiotic treatment on spontaneous conception. Am J Reprod Immunol. 2018;79:e12782. PMID: 29135053 DOI: 10.1111/aji.12782

Coughlan C, Ledger W, Wang Q, Liu F, Demirol A, Gurgan T, Cutting R, Ong K, Sallam H, Li TC. Recurrent implantation failure: definition and management. Reprod Biomed Online. 2014;28:14-38. PMID: 24269084 DOI: 10.1016/j. rbmo.2013.08.011

Dickey RP, Olar TT, Curole DN, Taylor SN, Rye PH. Endometrial pattern and thickness associated with pregnancy outcome after assisted reproduction technologies. Hum Reprod. 1992;7:418-21. PMID: 1587952 DOI: 10.1093/ oxfordjournals.humrep.a137661

Eftekhar M, Tabibnejad N, Tabatabaie AA. The thin endometrium in assisted reproductive technology: An ongoing challenge. Middle East Fertil Soc J. 2018;23:1-7. DOI: 10.1016/j.mefs.2017.12.006

El-Toukhy T, Coomarasamy A, Khairy M, Sunkara K, Seed $P$, Khalaf $Y$, Braude P. The relationship between endometrial thickness and outcome of medicated frozen embryo replacement cycles. Fertil Steril. 2008;89:832-9. PMID: 17681313 DOI: $10.1016 /$ j.fertnstert.2007.04.031

Gaengel K, Genové G, Armulik A, Betsholtz C. Endothelial-mural cell signaling in vascular development and angiogenesis. Arterioscler Thromb Vasc Biol. 2009;29:630-8. PMID: 19164813 DOI: 10.1161/ATVBAHA.107.161521

Gargett CE, Ye L. Endometrial reconstruction from stem cells. Fertil Steril. 2012;98:11-20. PMID: 22657248 DOI: $10.1016 /$ j.fertnstert.2012.05.004

Gargett CE, Schwab KE, Deane JA. Endometrial stem/ progenitor cells: the first 10 years. Hum Reprod Update. 2016;22:137-63. PMID: 26552890 DOI: $10.1093 /$ humupd/dmv051

Glissant A, de Mouzon J, Frydman R. Ultrasound study of the endometrium during in vitro fertilization cycles. Fertil Steril. 1985;44:786-90. PMID: 4076435 DOI: 10.1016/ S0015-0282(16)49038-2 
Gordon JD, Shifren JL, Foulk RA, Taylor RN, Jaffe RB. Angiogenesis in the human female reproductive tract. Obstet Gynecol Surv. 1995;50:688-97. PMID: 7478421 DOI: 10.1097/00006254-199509000-00024

Johnston-MacAnanny EB, Harnett J, Engmann LL, Nulsen JC, Sanders MM, Benadiva CA. Chronic endometritis is a frequent finding in women with recurrent implantation failure after in vitro fertilization. Fertil Steril. 2010;93:437-41. PMID: 19217098 DOI: 10.1016/j.fertnstert.2008.12.131

Kashida S, Sugino N, Takiguchi S, Karube A, Takayama H, Yamagata Y, Nakamura Y, Kato $\mathrm{H}$. Regulation and role of vascular endothelial growth factor in the corpus luteum during mid-pregnancy in rats. Biol Reprod. 2001;64:31723. PMID: 11133689 DOI: 10.1095/biolreprod64.1.317

Kitaya K, Matsubayashi H, Takaya Y, Nishiyama R, Yamaguchi $\mathrm{K}$, Takeuchi T, Ishikawa T. Live birth rate following oral antibiotic treatment for chronic endometritis in infertile women with repeated implantation failure. Am J Reprod Immunol. 2017:78:e12719. PMID: 28608596 DOI: 10.1111/aji.12719

Kotaro K, Matsubayashi H, Takaya Y, Nishiyama R, Yamaguchi K, Takeuchi T, Ishikawa T. Live birth rate following oral antibiotic treatment for chronic endometritis in infertile women with repeated implantation failure. Am J Reprod Immunol. 2017;78:e12719. PMID: 28608596 DOI: 10.1111/aji.12719

Kovacs P, Matyas S, Boda K, Kaali SG. The effect of endometrial thickness on IVF/ICSI outcome. Hum Reprod. 2003;18:2337-41. PMID: 14585884 DOI: $10.1093 /$ humrep/deg461

Lash GE, Schiessl B, Kirkley M, Innes BA, Cooper A, Searle RF, Robson SC, Bulmer JN. Expression of angiogenic growth factors by uterine natural killer cells during early pregnancy. J Leukoc Biol. 2006;3:572-80. PMID: 16816146 DOI: $10.1189 / \mathrm{jlb} .0406250$

Lebovitz O, Orvieto R. Treating patients with "thin" endometrium - an ongoing challenge. Gynecol Endocrinol. 2014;30:409-14. PMID: 24693854 DOI: $10.3109 / 09513590.2014 .906571$

Mahajan N, Sharma S. The endometrium in assisted reproductive technology: How thin is thin? J Hum Reprod Sci. 2016;9:3-8. PMID: 27110071 DOI: 10.4103/09741208.178632

Masuda $H$, Matsuzaki $Y$, Hiratsu E, Ono M, Nagashima T, Kajitani $T$, Arase $T$, Oda H, Uchida H, Asada H, Ito M, Yoshimura Y, Maruyama T, Okano $\mathrm{H}$. Stem cell-like properties of the endometrial side population: implication in endometrial regeneration. PLoS One. 2010;5:e10387. PMID: 20442847 DOI: 10.1371/journal.pone.0010387

Masuda H, Anwar SS, Bühring HJ, Rao JR, Gargett CE. A novel marker of human endometrial mesenchymal stem-like cells. Cell Transplant. 2012;21:2201-14. PMID: 22469435 DOI: 10.3727/096368911X637362

Masuda H, Maruyama T, Gargett CE, Miyazaki K, Matsuzaki $Y$, Okano $\mathrm{H}$, Tanaka M. Endometrial side population cells: potential adult stem/progenitor cells in endometrium. Biol Reprod. 2015;93:84. PMID: 26316062 DOI: 10.1095/biolreprod.115.131490
McQueen DB, Bernardi LA, Stephenson MD. Chronic endometritis in women with recurrent early pregnancy loss and/ or fetal demise. Fertil Steril. 2014;101:1026-30. PMID: 24462055 DOI: $10.1016 /$ j.fertnstert.2013.12.031

Mills SJ, Cowin AJ, Kaur P. Pericytes, mesenchymal stem cells and the wound healing process. Cells. 2013;2:62134. PMID: 24709801 DOI: 10.3390/cells2030621

Miwa I, Tamura H, Takasaki A, Yamagata $Y$, Shimamura K, Sugino N. Pathophysiologic features of "thin" endometrium. Fertil Steril. 2009;91:998-1004. PMID: 18328483 DOI: $10.1016 /$ j.fertnstert.2008.01.029

Möhle R, Green D, Moore MA, Nachman RL, Rafii S. Constitutive production and thrombin-induced release of vascular endothelial growth factor by human megakaryocytes and platelets. Proc Natl Acad Sci USA. 1997;94:663-8. PMID: 9012841 DOI: $10.1073 /$ pnas.94.2.663

Nguyen HPT, Xiao L, Deane JA, Tan KS, Cousins FL, Masuda $\mathrm{H}$, Sprung CN, Rosamilia A, Gargett CE. N- cadherin identifies human endometrial epithelial progenitor cells by in vitro stem cell assays. Hum Reprod. 2017;32:2254-68. PMID: 29040564 DOI: 10.1093/humrep/dex289

Noyes R, Hertig AT, Rock J. Dating the endometrial biopsy. Fertil Steril. 1950;1:3-25. DOI: 10.1016/S00150282(16)30062-0

Park HJ, Kim YS, Yoon TK, Lee WS. Chronic endometritis and infertility. Clin Exp Reprod Med. 2016;43:185-92. PMID: 28090456 DOI: 10.5653/cerm.2016.43.4.185

Polanski LT, Baumgarten MN, Quenby S, Brosens J, Campbell BK, Raine-Fenning NJ. What exactly do we mean by recurrent implantation failure? A systematic review and opinion. Reprod Biomed Online. 2014;28:409-23. PMID: 24581986 DOI: $10.1016 /$ j.rbmo.2013.12.006

Ribeiro A, Laranjeira $P$, Mendes S, Velada I, Leite C, Andrade P, Santos F, Henriques A, Grãos M, Cardoso CM, Martinho A, Pais M, da Silva CL, Cabral J, Trindade H, Paiva A. Mesenchymal stem cells from umbilical cord matrix, adipose tissue and bone marrow exhibit different capability to suppress peripheral blood B, natural killer and T cells. Stem Cell Res Ther. 2013;4:125. PMID: 24406104 DOI: 10.1186/scrt336

Rogers PA, Lederman F, Taylor N. Endometrial microvascular growth in normal and dysfunctional states. Hum Reprod Update. 1998;4:503-8. PMID: 10027602 DOI: 10.1093/ humupd/4.5.503

Rossignoli F, Caselli A, Grisendi G, Piccinno S, Burns JS, Murgia A, Veronesi E, Loschi P, Masini C, Conte P, Paolucci $P$, Horwiz EM, Dominici M. Isolation, characterization, and transduction of endometrial decidual tissue multipotent mesenchymal stromal/stem cells from menstrual blood. Biomed Res Int. 2013;2013:901821. PMID: 23607099 DOI: $10.1155 / 2013 / 901821$

Salatino DR. Fundamentals of a new research method. Inter J Res Methodol Soc Sci. 2019;5:52-73. DOI: 10.5281/ zenodo. 2667563

Schwab KE, Gargett CE. Co-expression of two perivascular cell markers isolates mesenchymal stem-like cells from human endometrium. Hum Reprod. 2007;22:2903-11. PMID: 17872908 DOI: 10.1093/humrep/dem265 
Scioscia M, Lamanna G, Lorusso F, Serrati G, Selvaggi LE, Depalo R. Characterization of endometrial growth in proliferative and early luteal phase in IVF cycles. Reprod Biomed Online. 2009;18:73-8. PMID: 19146772 DOI: 10.1016/ S1472-6483(10)60427-0

Sharkey AM, Day K, McPherson A, Malik S, Licence D, Smith SK, Charnock-Jones DS. Vascular endothelial growth factor expression in human endometrium is regulated by hypoxia. J Clin Endocrinol Metab. 2000;85:402-9. PMID: 10634417 DOI: $10.1210 /$ jc.85.1.402

Simon A, Laufer N. Repeated implantation failure: clinical approach. Fertil Steril. 2012;97:1039-43. PMID: 22464086 DOI: $10.1016 /$ j.fertnstert.2012.03.010

Singh N, Mohanty S, Seth T, Shankar M, Bhaskaran S, Dharmendra S. Autologous stem cell transplantation in refractory Asherman's syndrome: A novel cell based therapy. J Hum Reprod Sci. 2014;7:93-8. PMID: 25191021 DOI: $10.4103 / 0974-1208.138864$

Sugino N, Kashida S, Karube-Harada A, Takiguchi S, Kato $\mathrm{H}$. Expression of vascular endothelial growth factor (VEGF) and its receptors in human endometrium throughout the menstrual cycle and in early pregnancy. Reproduction. 2002;123:379-87. PMID: 11882015 DOI: 10.1530/ rep. 0.1230379

Teklenburg G, Salker M, Heijnen C, Macklon NS, Brosens J]. The molecular basis of recurrent pregnancy loss: impaired natural embryo selection. Mol Hum Reprod. 2010;16:88695. PMID: 20847090 DOI: $10.1093 / \mathrm{molehr} /$ gaq079
Tersoglio AE, Salatino DR, Reinchisi G, Gonzalez A, Tersoglio S, Marlia C. Repeated implantation failure in oocyte donation. What to do to improve the endometrial receptivity? JBRA Assist Reprod. 2015;19:44-52. PMID: 27206087 DOI: $10.5935 / 1518-0557.20150012$

Trundley A, Moffett A. Human uterine leukocytes and pregnancy. Tissue Antigens. 2004;1:1-12. PMID: 14651517 DOI: $10.1111 /$ j.1399-0039.2004.00170.x

Tsuji S, Yoshimoto M, Takahashi K, Noda Y, Nakahata T, Heike T. Side population cells contribute to the genesis of human endometrium. Fertil Steril. 2008;90:1528-37. PMID: 18462721 DOI: 10.1016/j.fertnstert.2007.08.005

Wang WJ, Zhang $\mathrm{H}$, Chen ZQ, Zhang W, Liu XM, Fang JY, Liu FJ, Kwak-Kim J. Endometrial TGF- $\beta$, IL-10, IL-17and autophagy are dysregulated in women with recurrent implantation failure with chronic endometritis. Reprod Biol Endocrinol. 2019;17:2. PMID: 30606202 DOI: 10.1186/ s12958-018-0444-9

Zhou C, Yang B, Tian Y, Jiao H, Zheng W, Wang J, Guan F. Immunomodulatory effect of human umbilical cord Wharton's jelly-derived mesenchymal stem cells on lymphocytes. Cell Immunol. 2011;272:33-8. PMID: 22004796 DOI: $10.1016 /$ j.cellimm.2011.09.010 